\title{
Stimulation of LH secretion in sheep by central administration of corticotrophin-releasing hormone
}

\author{
A. Caraty ${ }^{1}$, D. W. Miller ${ }^{2 *}$, B. Delaleu ${ }^{1}$ and G. B. Martin ${ }^{2}$ \\ ${ }^{1}$ INRA Station de Physiologie de la Reproduction des Mammifères Domestiques, 37380 Nouzilly, France; \\ and ${ }^{2}$ Faculty of Agriculture (Animal Science), The University of Western Australia, Nedlands WA 6907, \\ Australia
}

Corticotrophin-releasing hormone $(\mathrm{CRH})$ has been proposed as a mediator of the antireproductive effects of stress through an action within the hypothalamus to inhibit GnRH secretion. This hypothesis was tested in sheep by studying the responses to central administration of CRH in both sexes and in both seasons. Sexually mature, Ile-de-France ewes and Romanov rams that had been gonadectomized and implanted with a permanent guide cannula into the third cerebral ventricle were used. Ewes were studied in the presence and absence of exogenous oestradiol plus progesterone, in both the breeding and anoestrous seasons. All rams were treated with testosterone and were studied only during the breeding season. Each observation involved serial samples (every $10 \mathrm{~min}$ ) of jugular blood for $5 \mathrm{~h}$ before (control) and $5 \mathrm{~h}$ after an intracerebroventricular (icv) injection of either saline (vehicle) or 5 nmoles $\mathrm{CRH}$ in $20 \mu \mathrm{l}$ vehicle. The saline injections did not affect any of the endocrine variables measured; however, $\mathrm{CRH}$ always increased cortisol concentrations in jugular plasma. In the absence of treatment with replacement sex steroids, icv injection of $\mathrm{CRH}$ had no effect on pulsatile LH secretion in females either during the breeding season or during anoestrus. However, LH pulse frequency and mean LH concentrations increased significantly on every occasion on which animals were treated with sex steroids. Treatment with $\mathrm{CRH}$ also increased $\mathrm{LH}$ secretion in the testosterone-treated rams. It is concluded that, contrary to the hypothesized role of $\mathrm{CRH}$ as an inhibitor of reproductive activity, this neuropeptide stimulates pulsatile LH (and thus GnRH) secretion, at least in this species. The fact that gonadal steroids seem to be obligatory for the expression of this effect suggests that the protocols used in past studies need to be reassessed.

\section{Introduction}

Under stressful conditions, the neuropeptide, corticotrophinreleasing hormone $(\mathrm{CRH})$ is released into the hypophyseal portal system to activate the synthesis and release of ACTH from the pituitary gland (Rivier and Plotsky, 1986). In addition, $\mathrm{CRH}$ appears to act within the central nervous system of the rat to mediate the anti-reproductive effects of stress. For example, intracerebroventricular (icv) administration of $\mathrm{CRH}$ inhibits the secretion of GnRH into hypophyseal portal blood and decreases LH secretion (Rivier and Vale, 1984; Petraglia et al., 1987). The inhibition of $\mathrm{LH}$ secretion by footshock is also known to be associated with a large release of $\mathrm{CRH}$ into portal blood and can be reversed by icv administration of either CRH antagonist or antiserum directed against CRH (Rivier et al., 1986). There may be differences between species in the action of $\mathrm{CRH}$, as inhibition of $\mathrm{LH}$ secretion in gonadectomized monkeys caused by hypoglycaemic stress does not appear to be mediated by hypothalamic CRH (Van Vugt et al., 1997).

*Present address: MRC Reproductive Biology Unit, 37 Chalmers St, Edinburgh EH3 9EW, UK.

Received 18 February 1997
Immunohistochemical studies in the rat have lent anatomical support to the postulate of a central action of $\mathrm{CRH}$ on $\mathrm{GnRH}$ neurones. Synaptic contacts between $\mathrm{CRH}$ axon terminals and GnRH dendrites have been found in the medial preoptic area (MacLusky et al., 1988), a site where direct infusion of CRH inhibits GnRH release into the median eminence (Rivest et al., 1993).

The relationship between CRH and GnRH activities is not so clear in sheep. Stress is known to inhibit pulsatile LH secretion in gonadectomized and intact ewes (Rasmussen and Malven, 1983; Adams et al., 1993) and to suppress the preovulatory surge of LH in the intact ewe (Martin et al., 1980; Przekop et al., 1984). These effects are usually associated with increases in the circulating concentrations of cortisol. Under various stress conditions, a large increase in the secretion of $\mathrm{CRH}$ into hypophyseal portal blood has been demonstrated (Caraty et al., 1988a, 1990; Engler et al., 1989). Moreover, it has been reported that stress-induced $\mathrm{CRH}$ release into portal blood is correlated with a decrease in GnRH secretion in testosteronetreated gonadectomized rams (Papinot et al., 1989). However, peripheral administration of large quantities of $\mathrm{CRH}$ appears to have no effect on LH secretion, according to Donald et al. 
(1983) who worked with ewes for which neither ovarian status nor season were stated, and to Parrott et al. (1988) who worked with castrated rams. Clarke et al. (1990) observed no effect on LH secretion with icv administration of CRH, whereas Naylor et al. (1990) reported a stimulatory effect. Both of these studies used gonadectomized ewes that had not been treated with exogenous sex steroids. Taken together, these observations suggest that the sex steroid status of the animals needs to be adequately controlled in studies of interactions between the adrenal and gonadal axes.

We, therefore, reinvestigated the role of $\mathrm{CRH}$ in the control of reproduction in sheep by studying the responses to central administration of the neuropeptide. Gonadectomized animals were used to ensure control over the amount of sex steroids. The responses of females were studied during both sexual seasons; in the presence and absence of exogenous oestrogen or progesterone during anoestrus; and in the presence and absence of a combination of the sex steroids during the breeding season. Males were studied only in the breeding season in the presence of physiological doses of exogenous testosterone.

\section{Materials and Methods}

\section{Animals}

Sexually mature, Ile-de-France ewes and Romanov rams were housed indoors in separate, group pens, under natural photoperiod, at the INRA Station de la Reproduction des Mammifères Domestiques (Nouzilly). They were fed concentrated pellets once a day, and hay and water were available ad libitum. Experimental animals were always maintained in contact with other sheep, even during the sampling periods, to prevent the stress of social isolation (Rasmussen and Malven, 1983).

\section{Surgical procedures}

Guide-cannulae were constructed from blunted stainlesssteel luer-lock needles (o.d. $1.20 \mathrm{~mm}$; i.d. $0.86 \mathrm{~mm}$ ), cut to a length of $40 \mathrm{~mm}$ and stereotaxically implanted into the third cerebral ventricle according to a previously described procedure (Skinner et al., 1995). This operation was carried out under halothane anaesthesia in a stereotaxic frame with the aid of frontal and sagittal X-rays. The tip of the cannula was placed $1.5 \mathrm{~mm}$ behind the vertical tangent of the massa intermedia and $1.5 \mathrm{~mm}$ below the horizontal line which was drawn through the middle of the foramen of Monro. When the tip of the cannula was in the third ventricle, cerebrospinal (CSF) flowed freely back up the tube. The cannula was then closed with a stainless steel stylette with a plastic stopper and fixed to the skull with acrylic dental cement. The whole device was protected by a threaded cylindrical Teflon cap which was anchored to the skull with four stainless steel screws and acrylic cement. After surgery, animals were injected daily with antibiotics ( $5 \mathrm{ml}$ chloram-frecortyl; Vetoquinol, Lure, France) for 5 days and diuretics ( $3 \mathrm{ml}$ Diurizone; Vetoquinol) for 3 days. Chloram-frecortyl contains $0.22 \%$ prednisolone but this is cleared within $8 \mathrm{~h}$ and the animals were not used until a month after surgery.

\section{Blood sampling and injection procedure}

The day before each sampling period, a jugular cannula was inserted into each animal and kept patent with heparinized saline (50 units heparin $\mathrm{ml}^{-1}$ in saline). The next day, $5 \mathrm{ml}$ samples of blood were taken from each animal every $10 \mathrm{~min}$ for $10 \mathrm{~h}$, starting at $09.00 \mathrm{~h}$. After an initial $5 \mathrm{~h}$ control period, the animals were given an icv injection of either $\mathrm{CRH}$ ( 5 nmoles in $20 \mu \mathrm{l}$; Bachem, Marina del Rey, CA) or sterile saline (the vehicle), after which sampling continued for another $5 \mathrm{~h}$. The injections were aided by the insertion of a $20 \mathrm{~g}$ needle connected to $10 \mathrm{~cm}$ piece of polyethylene tubing (o.d.: $1.09 \mathrm{~mm}$; i.d.: $0.38 \mathrm{~mm}$ ) containing the injection solution. The needle was lowered to the required depth (extending $2 \mathrm{~mm}$ from the tip of the guide tube) and the injection was delivered under gravity.

\section{Experimental designs}

Experiment 1: treatment of gonadectomized ewes with $\mathrm{CRH}$ and sex steroids during the anoestrous season. Five Ile-de-France ewes that had been gonadectomized and implanted with permanent guide-cannulae into their third cerebral ventricles two months earlier were subjected to serial blood samples and icv injections on four occasions, one week apart, during the anoestrous season. The animals were injected with saline on the first occasion and with $\mathrm{CRH}$ on the others. The day after the first $\mathrm{CRH}$ injection, a $10 \mathrm{~mm}$ s.c. implant made from Silastic tubing (Dow Corning, Midland, MI) and filled with oestradiol, was inserted. These implants provide luteal phase amounts of oestradiol in the circulation ( $3 \mathrm{pg} \mathrm{ml}^{-1}$; Martin et al., 1988). The second CRH injection and serial blood sampling were carried out one week later. The oestradiol implant was then removed and animals were immediately given $3 \mathrm{~cm}$ intravaginal progesterone-releasing pessaries ('Plasthyd', Sanofi Research, Montpellier). This size and type of pessary has been shown to maintain circulating concentrations of progesterone at about $0.5-0.7 \mathrm{ng} \mathrm{ml}^{-1}$ for 12 days. These concentrations are lower than those normally observed during the luteal phase in intact ewes in our laboratory, but avoid a total blockade of LH pulsatile secretion, and thus allow detection of possible inhibitory effects of $\mathrm{CRH}$ administration. The final $\mathrm{CRH}$ injection and serial blood sampling were performed one week later.

\section{Experiment 2: treatment of gonadectomized ewes with $C R H$ and} sex steroids during the breeding season. Ten Ile-de-France ewes were gonadectomized and implanted with cerebral guidecannulae during the breeding season. Two months later, they were assigned to two groups of five animals. One group was treated with both oestradiol ( $1 \mathrm{~cm}$ s.c. implant) and progesterone $(3 \mathrm{~cm}$ intravaginal pessary) using the same implants as described for Expt 1. The other group did not receive any sex-steriod replacement treatment. After 15 days, two or three ewes from each group were injected (icv) with saline while the remainder were injected with $\mathrm{CRH}$. The day after these injections, the steroid and icv treatments were crossed over and a second series of samples was taken 15 days later, effectively providing five replicates for each of the four treatments. 


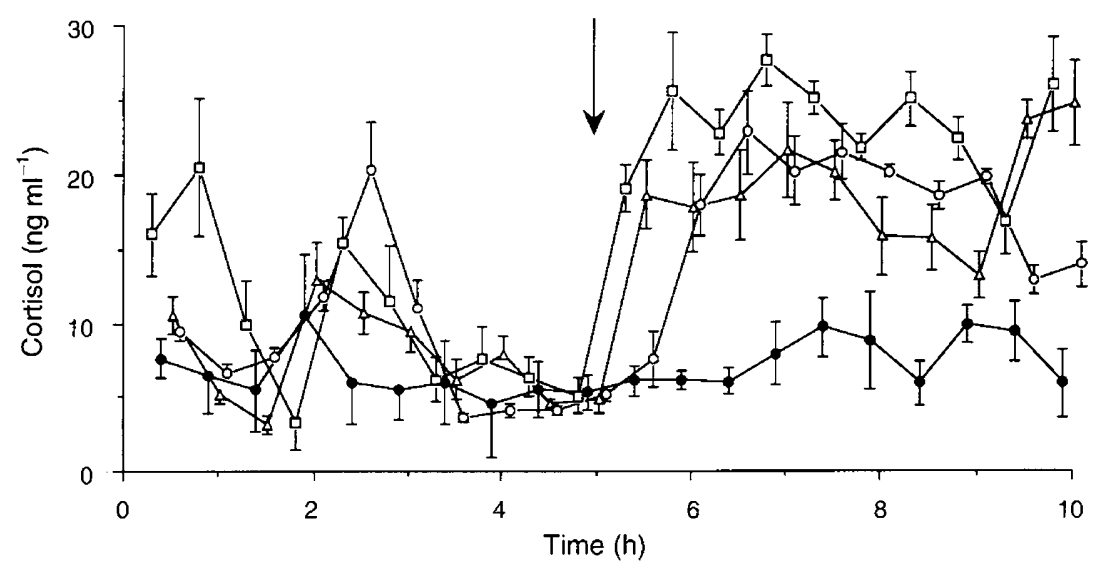

Fig. 1. Plasma concentrations of cortisol in gonadectomized ewes given intracerebroventricular injections (arrow) of saline ( $\bullet$ ) or corticotrophin-releasing hormone $(\mathrm{CRH})($ ) in the absence of exogenous sex steroids, or given $\mathrm{CRH}$ in the presence of oestrogen $(\mathrm{O})$ or progesterone $(\wedge)$. All values are mean $\pm \operatorname{SEM}(n=5)$.

Experiment 3: treatment of testosterone-implanted gonadectomized rams with $C R H$ during the breeding season. During the breeding season, four Romanov rams were implanted with permanent guide-cannulae into the third cerebral ventricle. One month later, animals were gonadectomized and given testosterone implants (s.c.) (Roussel UCLAF, Romainville) that have been shown to maintain circulating concentrations of testosterone at about $1 \mathrm{ng} \mathrm{ml}^{-1}$ for one month. Eight days later, serial blood samples were taken and the animals were injected icv with either saline or $\mathrm{CRH}$. One week later, the icv injection treatments were reversed during a second series of blood samples, effectively providing four replicates per treatment.

\section{Hormone assays}

Plasma collected from centrifuged blood samples was either assayed immediately or stored at $-20^{\circ} \mathrm{C}$ before assay. All samples from any given experiment were measured in one assay to avoid interassay variation. Plasma LH concentrations were measured in duplicate aliquots by radioimmunoassay using the method described by Pelletier et al. (1968). The sensitivity of the assay was $0.1 \mathrm{ng} \mathrm{ml} \mathrm{m}^{-1}$. The standard preparation (CY105I; kindly donated by $\mathrm{Y}$. Combarnous, INRA, Nouzilly) has an activity of $2.5 \times \mathrm{NIH}-\mathrm{LH}-\mathrm{S} 1$. The intra-assay coefficient of variation was $8 \%$. Testosterone concentrations were measured in duplicate aliquots by the radioimmunoassay using the method described by Garnier et al. (1978). The sensitivity of the assay was $0.1-0.2 \mathrm{ng} \mathrm{ml}^{-1}$ and the intra-assay coefficient of variation was 10\%. Progesterone concentrations were measured in duplicate aliquots by radioimmunoassay using the method described by Saumande et al. (1985). The sensitivity of the assay was $0.05 \mathrm{ng} \mathrm{ml}^{-1}$ and the intra-assay coefficient of variation was $10 \%$. Cortisol concentrations were measured in duplicate aliquots of every third sample (i.e., every $30 \mathrm{~min}$ ) taken in Expt I, using the radioimmunoassay described by Brunet and Sebastian (1991). The sensitivity of the assay was $0.2 \mathrm{ng} \mathrm{ml}^{-1}$ and the intra-assay coefficient of variation was $7.9 \%$.

\section{Statistical analyses}

The LH pulse profiles were analysed with a modified version of the 'Pulsar' algorithm modified for the Apple Macintosh computer ('Munro', Zaristow Software, West Morham, Haddington, East Lothian EH4 4PD, UK), as described by Martin et al. (1987). The baseline was calculated as a moving average over a 120 min window (60 min each side of the sample being tested). The individual peaks were tested with a threshold, where a pulse was accepted if the concentration at the peak exceeded the concentration at the previous nadir by more than one standard deviation and the interval to the previous pulse was more than $25 \mathrm{~min}$. The Baxter parameters, which describe the parabolic relationship between the mean and the standard deviation of the LH concentration, were derived from the quality controls for each assay. The G-parameters (the number of standard deviations by which a peak must exceed the baseline in order to be accepted) were set at 3.0, 2.5, 1.9, 1.2, and 0.9 standard deviations for pulses containing one to five samples above baseline concentration, respectively.

For each experiment, $\mathrm{LH}$ pulse frequencies observed before and after the icv infusions were compared using the Wilcoxon test for paired series. The other variables provided by the pulse analysis (mean concentration, interpulse nadir, pulse amplitude, pulse area) and the cortisol data were normally distributed, so the values before and after icv injection were compared using the Student's paired $t$ test. Control (pretreatment) values were tested where appropriate (for example, for responses to exogenous sex steroids) by one-way analysis of variance.

\section{Results}

Amongst all of the measures of $\mathrm{LH}$ secretion resulting from pulse analysis, only the pulse frequencies and the mean concentrations were affected by treatment. In the interests of brevity, these are the main data presented for this hormone.

\section{Experiment 1: treatment of gonadectomized ewes with $C R H$ and sex steroids during the anoestrous season}

Cortisol concentrations in jugular samples were not affected by icv administration of saline (Fig. 1), mean concentrations 
before and after treatment were $6.3 \pm 2.5$ versus $7.6 \pm 1.7 \mathrm{ng}$ $\mathrm{ml}^{-1}$, respectively. Injection of $\mathrm{CRH}$ increased $(P<0.05)$ cortisol concentrations, and the responses were similar in the absence of steroid replacement (increasing from $8.6 \pm 2.4 \mathrm{ng}$ $\mathrm{ml}^{-1}$ to $17.6 \pm 1.5 \mathrm{ng} \mathrm{ml}^{-1}$ ), in the presence of oestradiol $\left(6.8 \pm 1.6 \mathrm{ng} \mathrm{ml}^{-1}\right.$ to $\left.15.5 \pm 1.3 \mathrm{ng} \mathrm{ml}^{-1}\right)$, and in the presence of progesterone $\left(7.7 \pm 1.2 \mathrm{ng} \mathrm{ml}^{-1}\right.$ to $\left.19.2 \pm 2.4 \mathrm{ng} \mathrm{ml}^{-1}\right)$. The responses were thus similar in amplitude and duration in all groups (Fig. I).

Saline injected into the third ventricle did not alter any of the characteristics of LH secretion in gonadectomized ewes that were not treated with oestradiol (Fig. 2). Similarly, there were no significant responses to $\mathrm{CRH}$ in ewes not treated with oestradiol (Fig. 2). When gonadectomized ewes were treated with oestradiol, LH secretion was suppressed only one animal of the five showed a pulse during the $5 \mathrm{~h}$ before the injection. The pulse profiles observed in this situation suggest that icv CRH injections increase $\mathrm{LH}$ secretion in the presence of exogenous oestradiol (Fig. 3a), in contrast to the profiles observed in the absence of exogenous oestradiol (Fig. 3b). This result was supported by the statistical analysis for both LH pulse frequency $(P<0.05)$ and mean $\mathrm{LH}$ concentrations $(P<0.01)$ in animals treated with oestrogen (Fig. 2).

The progesterone pessaries increased plasma progesterone concentrations from $0.09 \pm 0.01 \mathrm{ng} \mathrm{ml}^{-1}$ to $0.69 \pm 0.18 \mathrm{ng} \mathrm{ml}^{-1}(P<0.05)$, but LH pulse frequency and mean concentrations did not differ from those observed in untreated, gonadectomized ewes (Fig. 2). Administration of $\mathrm{CRH}$ into the third ventricle of progesterone-treated ewes increased the mean $\mathrm{LH}$ concentrations $(P<0.001)$ but the increases in LH pulse frequency (Fig. 2), pulse amplitude $\left(6.1 \pm 0.5 \mathrm{ng} \mathrm{mi}^{-1}\right.$ to $\left.7.0 \pm 0.4 \mathrm{ng} \mathrm{ml}^{-1}\right)$, and nadir concentrations $\left(4.0 \pm 0.3 \mathrm{ng} \mathrm{ml}^{-1}\right.$ to $\left.4.8 \pm 0.5 \mathrm{ng} \mathrm{ml}^{-1}\right)$ were not significant.

\section{Experiment 2: treatment of gonadectomized ewes with $C R H$ and} sex steroids during the breeding season

As in the anoestrous season, icv injection of saline or CRH in gonadectomized ewes during the breeding season had no effect on LH secretion (Fig. 4). When gonadectomized animals were treated with a combination of oestrogen and progesterone, there was a significant decrease in L.H secretion $(P<0.01)$. Again, the pulse profiles suggested that icv $\mathrm{CRH}$ injections increased $\mathrm{LH}$ secretion in the presence of exogenous sex steroids (Fig. 3c), in contrast to the profiles observed in their absence (Fig. 3d). The statistical analysis showed that both LH pulse frequency and mean $\mathrm{LH}$ concentrations were increased $(P<0.05)$ by icv $C R H$ in ewes treated with oestradiol plus progesterone (Fig. 4).

\section{Experiment 3: treatment of testosterone-implanted gonadectomized} rams with $C R H$ during the breeding season

Plasma testosterone concentrations were $1.47 \pm 0.24 \mathrm{ng}$ $\mathrm{ml}^{-1}$ during the first sampling session and $1.36 \pm 0.57 \mathrm{ng}$ $\mathrm{ml}^{-1}$ during the second sampling session. The difference was not significant. As with the ewes, saline injection into the third
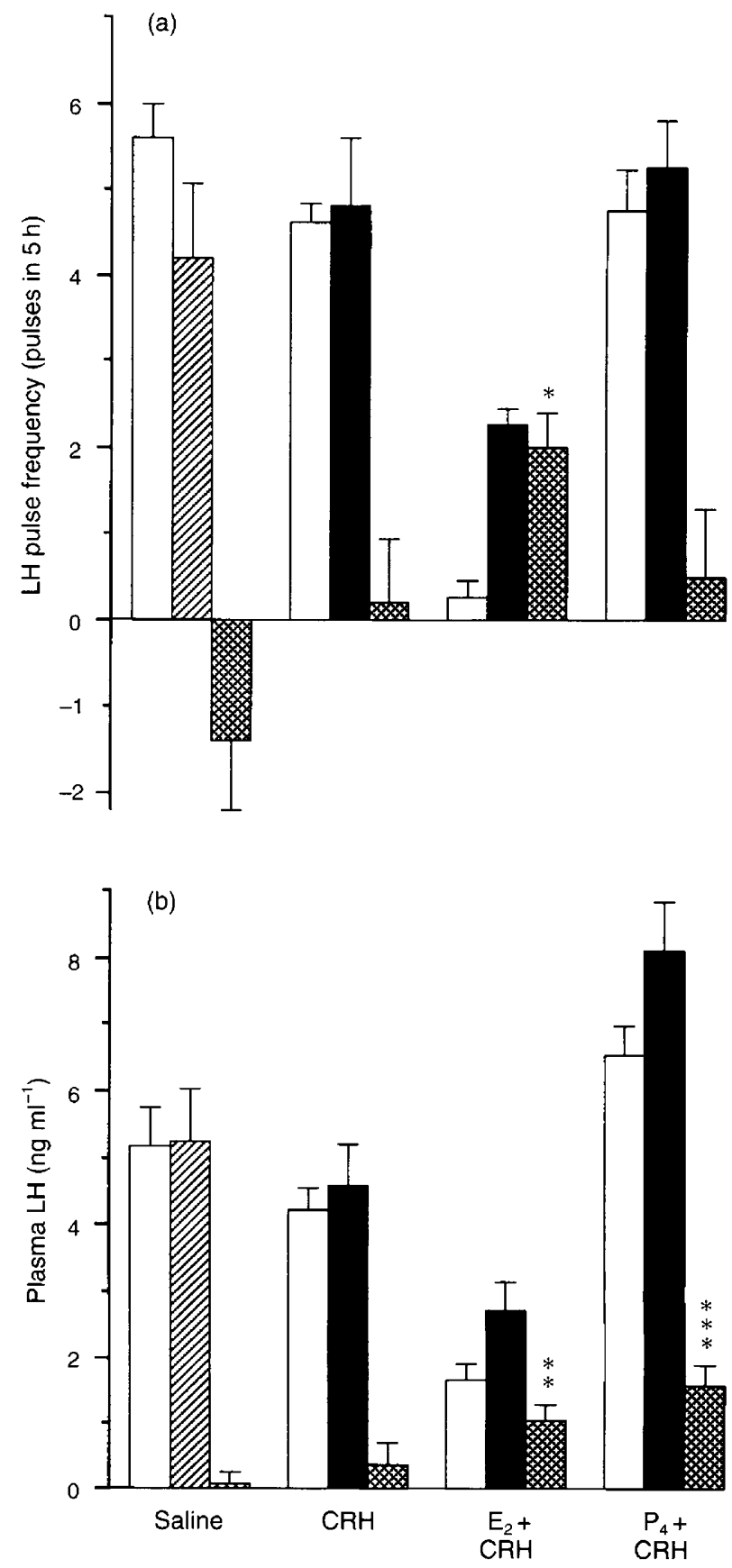

Fig. 2 (a) LH pulse frequencies and (b) mean LH concentrations in plasma in gonadectomized ewes over $5 \mathrm{~h}$, before treatment $(\square)$ and after intracerebroventricular injections of saline $(\varangle)$ or corticotrophinreleasing hormone $(\mathrm{CRH})(\mathbf{\square})$. The responses were observed with and without pretreatment with oestradiol $\left(E_{2}\right)$ or progesterone $\left(P_{4}\right)$ during the anoestrous season. Differences between values before and after injections ( were subjected to a paired $t$ test: ${ }^{*} P<0.05 ;{ }^{* *} P<0.01$; $* * * P<0.001$. All values are mean $\pm \operatorname{seM}(n=5)$.

cerebral ventricle had no effect on LH secretion in the rams. However, CRH administration increased the frequency of LH pulses (Fig. 5), as shown by a significant change in mean LH concentrations $(P<0.05)$ and a marginal change in pulse frequency $(P=0.067)$. 

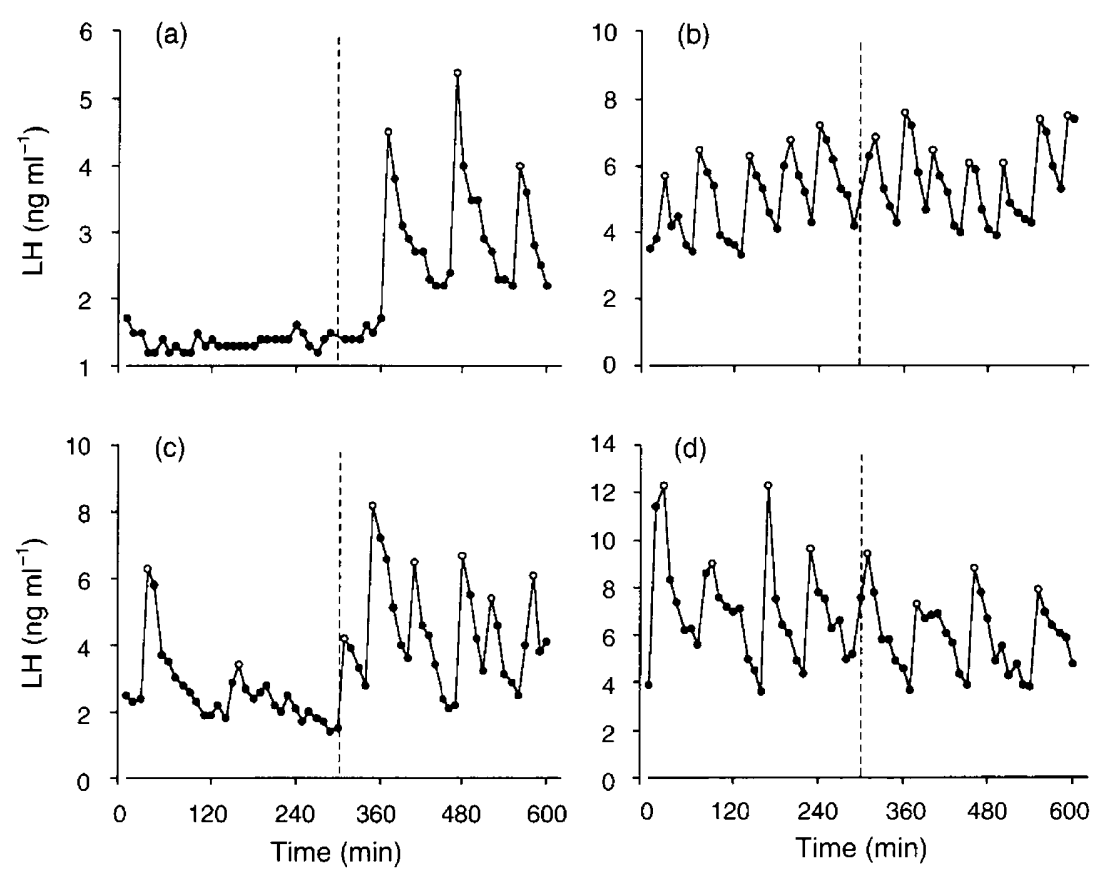

Fig. 3. Representative LH profiles showing responses of gonadectomized ewes to a single injection of corticotrophin-releasing hormone $(\mathrm{CRH})$ into the third cerebral ventricle. Ewes were treated with (a) exogenous oestradiol or (b) received no steroid treatment during the anoestrous season, or with (c) exogenous oestradiol plus progesterone or (d) did not receive steroid treatment during the breeding season. () in the profiles indicates significant pulses and the broken vertical lines indicate the time of administration of $\mathrm{CRH}$.

\section{Discussion}

The results of the three experiments reported here lead us to reject the hypothesis that hypothalamic $\mathrm{CRH}$ exerts an inhibitory effect on $\mathrm{GnRH}$ secretion in sheep. On the contrary, $\mathrm{CRH}$ administration induced clear and repeatable increases in $\mathrm{LH}$ secretion, an effect that appears to depend on the presence of sex steroids, at least in females. These observations differ markedly from those reported for rats (Petraglia et al., 1987) or monkeys (Olster and Ferin, 1987) and, together with other studies using sheep (Clarke et al., 1990, Naylor et al, 1990), they suggest a major species difference in the interactions at the hypothalamus between the corticotrophic and gonadotrophic axes.

The amount of $\mathrm{CRH}$ administered into the third ventricle was similar to that used by Naylor et al. (1990), but the physiological relevance of such a high dose needs to be considered, if only because the CSF concentrations achieved must be well above those usually observed in this compartment in sheep $\left(50-100 \mathrm{pg} \mathrm{ml}^{-1}\right.$; P. Poindron, personal communication). Rivier and Vale (1984) and Almeida et al. (1988) injected the same mass of CRH (thus giving a dose that is arguably higher on a body mass basis) into rats, and observed opposite effects on LH secretion to those observed in the present study in sheep. This difference is difficult to understand if the response is simply a pharmacological side-effect rather than a reflection of a normal action of $\mathrm{CRH}$. Moreover, higher icv doses of CRH $(50 \mu \mathrm{g})$ have been used to induce normal maternal behaviour in the female sheep (Keverne and Kendrick, 1991). Doses of this order are probably necessary to achieve
CRH concentrations typically found at the synaptic cleft because the peptide is rapidly cleared from the CSF, yet needs to diffuse from the ventricle to the target tissue.

Since the stimulatory effect of CRH was manifest as an increase in LH pulse frequency, it is very likely that it was due to activation of hypothalamic GnRH neurones (Clarke and Cummins, 1982, Caraty and Locatelli, 1988). The fact that, in females at least, the stimulatory effect of CRH was only observed in the presence of sex steroids, and then only when the LH pulse frequency was intrinsically low, raises the possibility that the response depends on the initial status of the $\mathrm{GnRH}$ pulse generator. This hypothesis is supported by data from ewes treated only with a low dose of progesterone during the anoestrous season, a treatment that did not significantly reduce $\mathrm{LH}$ pulse frequency. In this situation, $\mathrm{CRH}$ had no effect on LH pulse frequency and elicited only a small increase in LH concentrations. This finding contrasts with the situation in oestradiol-treated ewes during anoestrus, where LH pulses were almost completely blocked, as expected (see review by Martin, 1984). In this situation, CRH was able to induce very clear increases in pulsatile LH secretion. Similarly, LH secretion was stimulated by CRH during the breeding season in ovariectomized ewes treated with a combination of oestradiol and progesterone. In contrast, no changes were observed in gonadectomized ewes, during the breeding or anoestrous seasons, in the absence of ovarian steroids. This result agrees with a previous report by Clarke et al. (1990), although Naylor et al. (1990) reported a small, transitory increase in LH secretion with the same dose of $\mathrm{CRH}$ in the absence of sex steroids. This response was not affected by naloxone treatment, but this is 
(a)

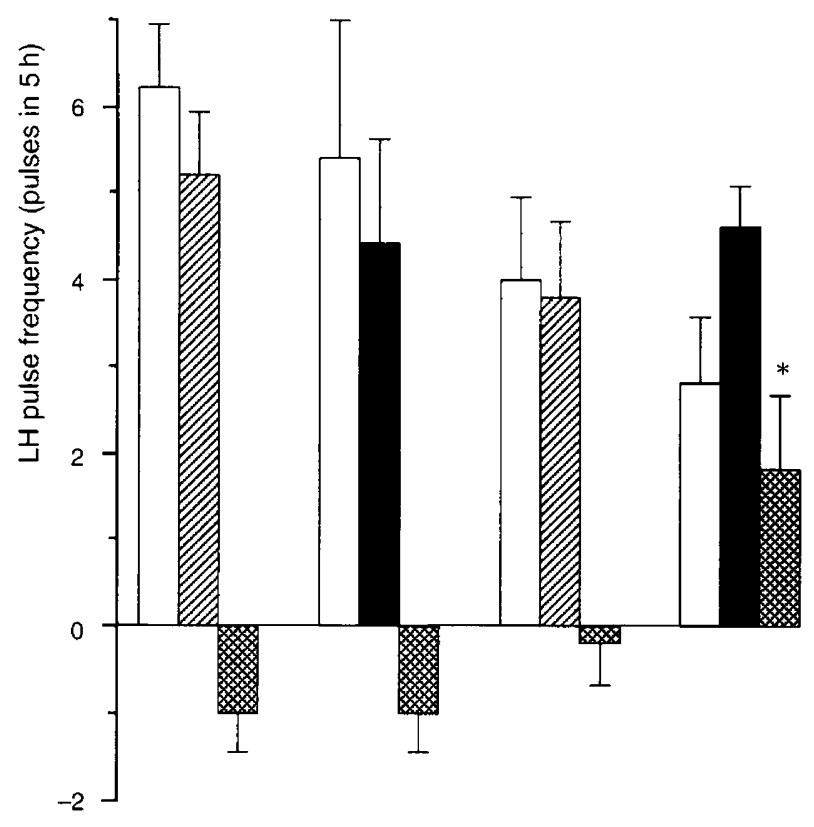

(b)

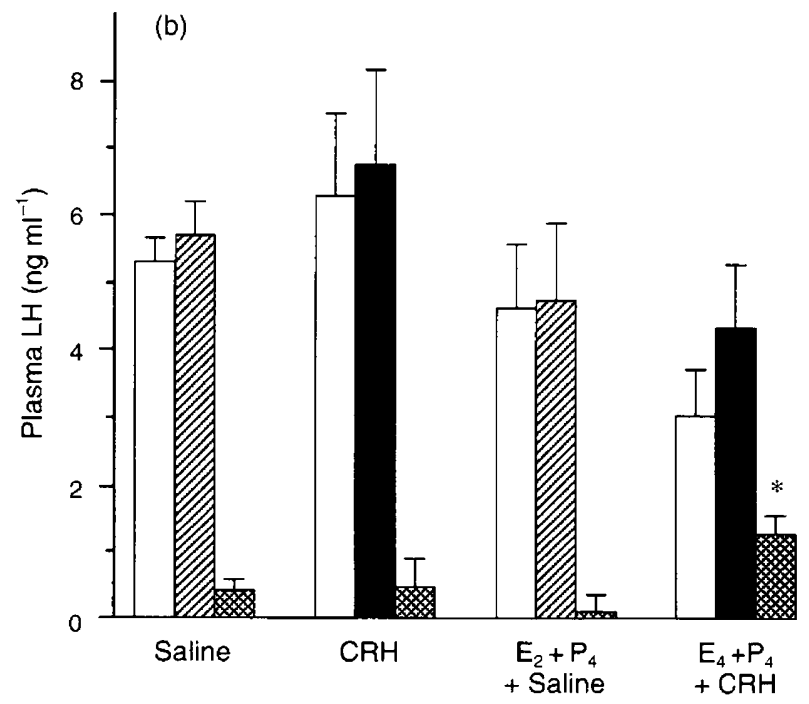

Fig. 4 (a) $\mathrm{LH}$ pulse frequencies and (b) mean LH concentrations in plasma in gonadectomized ewes before treatment $(\square)$ and after intracerebroventricular injection of saline (Ø) or corticotrophinreleasing hormone $(\mathrm{CRH})(\boldsymbol{\square})$. The responses were observed with and without pretreatment with oestradiol and progesterone $\left(\mathrm{E}_{2}+\mathrm{P}_{4}\right)$ during the breeding season. Differences between values before and after injections (国) were subjected to a paired $t$ test: ${ }^{*} P<0.05$. All values are mean $\pm \operatorname{SEM}(n=5)$.

perhaps not surprising since opioidergic control of gonadotrophin secretion in sheep depends largely on the presence of sex steroids (Brooks et al., 1986). The reasons for the differences between these studies are unclear and could be due to differences in the breed used, or differences in time after castration.

Several hypotheses can be advanced to explain the stimulatory effect of $\mathrm{CRH}$ on $\mathrm{GnRH}$ secretion in the presence of sex steroids. First, CRH is an excitatory peptide (Siggins et al., 1985) and may thus stimulate pathways that have positive effects on GnRH secretion. For example, it has been shown that LH secretion is increased by icv administration of enkephalins in long-term gonadectomized rats (Motta and Martini, 1982) and by morphine in intact male rats (Piva et al., 1986), and CRH itself is able to stimulate the release of $\beta$-endorphin, dynorphin and enkephalin from hypothalamic tissue (Nikolarakis et al., 1986). The connections between the CRH and GnRH neurones might be altered by sex steroids; it is well known that progesterone and oestradiol affect the morphology of the central nervous system (Raisman and Field, 1973) and recent studies have shown that gonadal steroids modulate the effect of endogenous $\mathrm{CRH}$ on the gonadal axis. CRH administration inhibits LH secretion in gonadectomized monkeys and rats through a mechanism that depends partially on opioid tone (Gindoff and Ferin, 1987; Olster and Ferin, 1987; Almeida et al., 1988). However, a similar stimulus is totally ineffective in ovary-intact monkeys, in the follicular or luteal phases (Norman, 1994). Long-term gonadectomized rats do not show a reduction in serum $\mathrm{LH}$ concentrations in response to an opioid agonist (Almeida et al., 1987) or CRH (Nikolarakis et al., 1988). Thus, it appears that sex steroids raise the opioid tone in the hypothalamus and, therefore, allow full expression of CRH effects on $\mathrm{GnRH}$ secretion. In gonadectomized female monkeys, CRH is itself able to stimulate the release of $\beta$-endorphin (Nikolarakis et al., 1986), yet LH secretion is inhibited by an interleukin-1-induced CRH release, and pretreatment with oestradiol leads to stimulation of both $\mathrm{LH}$ and corticotrophin secretion (Ferin, 1995). Such observations show that the effects of stress on the reproductive axis are more complex than have been imagined, and they also suggest that care is needed when interpreting studies in animals deprived of sex steroids. Moreover, $\mathrm{CRH}$ may be associated with changes in $\mathrm{GnRH}$ secretion through more than one pathway, only one of which (perhaps inhibitory) is related to stress.

Central administration of $\mathrm{CRH}$ also released cortisol into the general circulation. This release was not observed with the saline injection, so it was not due to any stress that might have been associated with the technique. Naylor et al. (1990) used one tenth of the dose of CRH used in the present study, and also observed an increase in cortisol secretion. The most likely explanation is sequestration of the hormone from the CSF by the tanycytes of the basement membrane of the third cerebral ventricle (Ben-Jonathan et al, 1974; Oldfield et al., 1985), followed by transport to the anterior pituitary gland, from where $\mathrm{ACTH}$ is released. Given that $\mathrm{ACTH}$ and cortisol have an inhibitory effect on LH secretion (Dobson et al., 1988; Porter et al., 1990), and that no differences between the sex steroid treatments in the cortisol response to $\mathrm{CRH}$ were found, it is very unlikely that $\mathrm{CRH}$ transported to the pituitary gland can account for the increases in $\mathrm{LH}$ secretion observed in the steroid-treated animals.

An earlier study with gonadectomized rams showed no effect of peripheral CRH administration on $\mathrm{LH}$ secretion (Parrot et al., 1988), perhaps because the route of peptide administration was inappropriate or because, in the absence of testosterone, the GnRH pulse generator was already operating near maximum frequency thus preventing detection of further increases. In any case, there is little real evidence that hypothalamic CRH inhibits GnRH secretion in male sheep. The observation that hypoglycaemia simultaneously increases $\mathrm{CRH}$ 

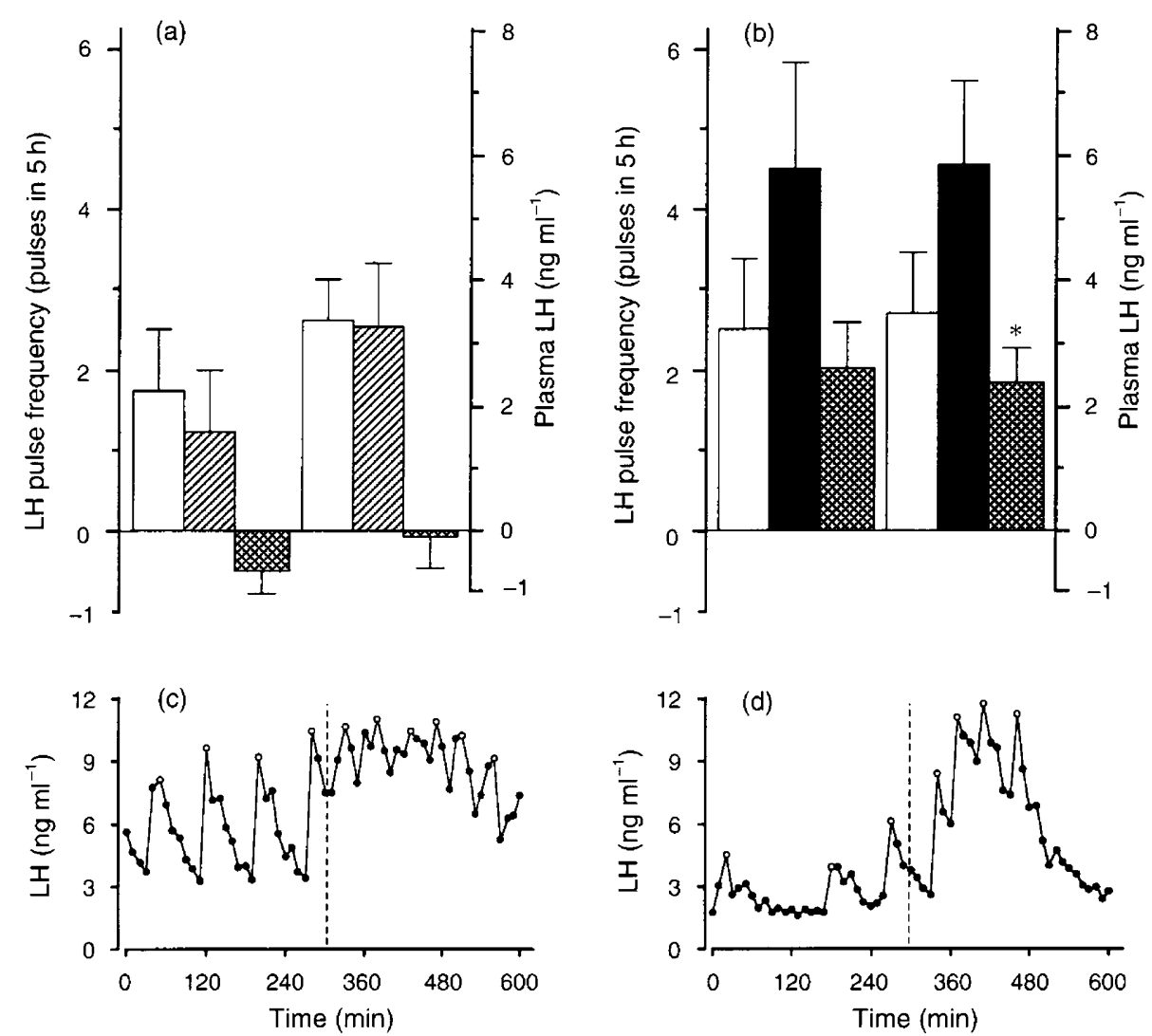

Fig. 5. LH pulse frequencies and plasma LH concentrations in testosterone-implanted gonadectomized rams, before treatment ( $\square$ ) and after intracerebroventricular injections of (a) saline ( $\square \Delta$ ) or (b) corticotrophin-releasing hormone $(\mathrm{CRH})(\boldsymbol{\sigma})$ during the breeding season. Values before and after injections were subjected to a paired $t$ test: ${ }^{*} P<0.05$ for concentration, $P=0.067$ for frequency (All values are mean $\pm \operatorname{SEM}(n=4)$. The LH profiles shown in (c, d) are from two rams treated with CRH. (): significant pulses.

and decreases $\mathrm{GnRH}$ secretion into the hypophyseal portal bloodstream in testosterone-treated, gonadectomized rams (Papinot et al., 1989) is countered by the fact that haemorrhage increases CRH secretion but has no effect on GnRH secretion in gonadectomized rams (Caraty et al, 1988b). Both of these experiments were carried out in the same laboratory as the present studies showing that $\mathrm{CRH}$ stimulates $\mathrm{GnRH}$ release, so it seems most unlikely that the suppression of GnRH secretion by hypoglycaemia is due to a direct action of the CRH on GnRH neuronal activity. The same seems to apply to female sheep and monkeys, in which activation of the hypothalamopituitary-adrenocortical axis did not appear to be responsible for the decrease in LH secretion following insulin-induced hypoglycaemia (Clarke et al., 1990; Van Vugt et al, 1997). Moreover, as the response to central CRH administration was not altered by naloxone (Naylor et al., 1990), the enhancement of the response to CRH by testosterone is not likely to be due to a steroid-dependent opioidergic pathway, such as that which seems to mediate the inhibitory effect of $\mathrm{CRH}$ in rats (Nikolarakis et al., 1988). It is thus probable that the inhibition of GnRH secretion by hypoglycaemia (Papinot et al., 1989) was due to other factors released by the stress (such as vasopressin and noradrenaline) that overrode, or were even independent of, the pathways through which CRH stimulates LH release.
It is clear that $\mathrm{CRH}$ is a neurotransmitter of the stressresponsive pathway in sheep (Caraty et al., 1988; 1990; Engler et al., 1989) and this role of CRH makes it difficult to explain why icv CRH stimulates LH secretion in this species. However, it should be considered that, in many species, stress itself can be both a stimulatory and an inhibitory influence on the gonadotrophic axis, depending on the novelty, duration and intensity of the stimulus. Chronic stress usually inhibits LH secretion (Gray et al., 1978; Rasmussen and Malven, 1983) but acute stress appears to be stimulatory (Armario et al., 1987; Hayashi and Moberg, 1987). It is possible, therefore, that the CRHinduced $\mathrm{LH}$ release observed in the present experiments results from the activation of such stress-responsive stimulatory pathway on LH secretion. Moreover, many 'chronic' stressors appear to become acute through habituation and 'reboundí effects (Adams et al., 1993; Martin 1995). This property has been used in the past, perhaps unwittingly, to induce reproductive function in farm animals. For example, the stress of transport can induce ovulation in anoestrous ewes (Braden and Moule, 1964) and puberty in prepubertal sows (Du Mesnil du Buisson and Signoret, 1962), and the stress of blood sampling can induce multiple ovulation in cyclic ewes (Adams et al., 1993). A very important consideration here is the need to distinguish between the effects of central $\mathrm{CRH}$ on $\mathrm{GnRH}$ 
secretion and the effects of stress on GnRH and CRH secretion into the pituitary portal circulation, because these responses may not be linked.

In summary, the results presented here show that central $\mathrm{CRH}$ administration into gonadectomized sheep can induce a pronounced increase in LH secretion, particularly when the gonadal steroids have been replaced. The lack of an inhibitory effect suggests that CRH is not involved in any inhibition of reproduction by stressors. Further experimentation is now required to test whether hypothalamic CRH plays an important role in the pathways that control the gonadotrophic axis.

The standard LH preparation (CY1051) was kindly donated by Y. Combarnous (INRA, Nouzilly). Travel funding for D.W. Miller was provided by the Convocation of The University of Western Australia. We are grateful to the French Ministère de la Recherche et de la Technologie (MRT) for the financial support that brought G.B. Martin to the INRA Station at Nouzilly.

\section{References}

Adams NR, Atkinson S, Martin GB, Briegel JR, Boukhliq R and Sanders MR (1993) Frequent blood sampling changes the plasma concentration of $\mathrm{LH}$ and FSH and the ovulation rate in Merino ewes Journal of Reproduction and Fertility $\mathbf{9 9}$ 689-694

Almeida OFX, Nikolarakis KE, Schulz R and Herz A (1987) A 'window of time' during which testosterone determines the opiatergic control of $\mathrm{LH}$ release in the adult male rat Journal of Reproduction and Fertility 79 299-305

Almeida OFX, Nikolarakis KE and Herz A (1988) Evidence for the involvement of endogenous opioids in the inhibition of luteinizing hormone by corticotropin-releasing factor Endocrinology 122 1034-1041

Armario A, Restrepo C, Hildalgo J and Lopez-Calderon A (1987) Differences in prolactin and LH responses to acute stress between peripubertal and adult male rats Journal of Endocrinology 112 9-13

Ben-Jonathan N, Mical RS and Porter JC (1974) Transport of LRF from CSF to hypophysial portal and systemic blood and release of LH Endocrinology 95 $18-25$

Braden AWH and Moule GR (1964) Effect of stress on ovarian morphology and oestrous cycles in ewes Australian Journal of Agricultural Research 15 937-949

Brooks AN, Haynes NB, Yang K and Lamming GE (1986) Ovarian steroid involvement in endogenous opioid modulation of LH secretion in seasonally anoestrous mature ewes Journal of Reproduction and Fertility 76 709-715

Brunet AG and Sebastian AL (1991) Effect of season on plasma concentrations of prolactin and cortisol in pregnant, non-pregnant and lactating ewes Animal Reproduction Sciences 26 251-268

Caraty A and Locatelli A (1988) Effect of time after castration on secretion of LHRH and LH in the ram Journal of Reproduction and Fertility 82 263-269

Caraty A, Grino A, Locatelli A and Oliver C (1988a) Secretion of corticotropinreleasing factor (CRF) and vasopressin (AVP) into hypophyseal portal blood of conscious, unrestrained rams Biochemical and Biophysical Research Communications 155 841-849

Caraty A, Locatelli A, Grino A and Oliver C (1988b) Hemorrhage-induced secretion of corticotropin-releasing factor (CRF) does not decrease luteinizing hormone-releasing hormone (LH-RH) release in hypophyseal portal blood circulation of castrated rams 11th International Congress on Animal Reproduction and Artificial Insemination, 26-30 June 1988, Dublin Vol. 2 p 16

Caraty A, Grino A, Locatelli A, Guillaume V, Boudouresque F and Oliver C (1990) Insulin-induced hypoglycemia stimulates corticotropin-releasing factor (CRF) and arginine vasopressin (AVP) secretion into hypophyseal portal blood of conscious, unrestrained rams Journal of Clinical Investigations 85 1716-1721

Clarke IJ and Cummins JT (1982) The temporal relationship between gonadotropin releasing hormone $(\mathrm{GnRH})$ and luteinizing hormone $(\mathrm{LH})$ secretion in the ovariectomized ewe Endocrinology 111 1737-1739

Clarke IJ , Horton RJE and Doughton BW (1990) Investigation of the mechanism by which insulin induced hypoglycemia decreases luteinizing secretion in ovariectomized ewes Endocrinology 127 1470-1476
Dobson H, Essawy SA and Alam MGS (1988) Suppression of LH response to gonadotrophin-releasing hormone or oestradiol by ACTH (1-24) treatment in anoestrous ewes Journal of Endocrinology 118 193-197

Donald RA, Redekopp C, Cameron V, Nicholls MG, Bolton J, Liversey J, Espiner EA, Rivier J and Vale W (1983) The hormonal actions of corticotropinreleasing factor in sheep; effects of intravenous and intracerebroventricular injection Endocrinology $113866-870$

Du Mesnil du Buisson F and Signoret JP (1962) Influence des facteurs externes sur le déclenchement de la puberté chez la truie Annales de Zootechnie 11 53-59

Engler D, Pham T, Fullerton MJ, Ooi G, Funder JW and Clarke IJ (1989) Studies of the secretion of corticotropin-releasing factor and arginine vasopressin into hypophysial-portal circulation of conscious sheep Neuroendocrinology $49367-381$

Ferin M (1995) The antireproductive role of corticotropin releasing hormone and interleukin- 1 in the female rhesus monkey Annales d'Endocrinologie 56 181-186

Garnier DH, Cotta $Y$ and Terqui M (1978) Androgen radioimmunoassay in the ram: results of direct plasma testosterone and dehydroepiandrosterone measurement and physiological evaluation Reproduction Nutrition and Development 18 265-281

Gindoff PR and Ferin M (1987) Endogenous opioid peptides modulate the effect of corticotropin-releasing factor on gonadotropin release in primates Netroendocrinology 49 202-206

Gray GD, Smith ER, Damassa DA, Ehrenkranz JRL and Davidson JM (1978) Neuroendocrine mechanisms mediating the suppression of circulating testosterone levels associated with chronic stress in male rat Neuroendocrinology $\mathbf{2 5}$ 247-256

Hayashi KT and Moberg GP (1987) Influence of acute stress and the adrenal axis on regulation of $\mathrm{LH}$ and testosterone in the male rhesus monkey (Macaca mulatta) American Journal of Primatology 12 263-273

Keverne EB and Kendrick KM (1991) Morphine and corticotrophin-releasing factor potentiate maternal acceptance in multiparous ewes after vaginocervical stimulation Brain Research $\mathbf{5 4 0} 55-62$

MacLusky NJ, Naftolin F and Leranth C (1988) Immunocytochemical evidence for a direct synaptic connection between corticotropin-releasing factor (CRF) and gonadotropin-releasing hormone (GnRH)-containing neurons in the preoptic area of the rat Brain Research 439 391-395

Martin GB (1984) Factors affecting the secretion of luteinizing hormone in the ewe Biological Review 59 1-87

Martin GB (1995) Reproductive research on farm animals for Australia - some long-distance goals Reproduction, Fertility and Development 7 967-982

Martin GB, Oldham CM and Lindsay DR (1980) Effect of stress due to laparoscopy on plasma cortisol levels, the preovulatory surge of $\mathrm{LH}$ and ovulation in the ewe Theriogenology 16 39-44

Martin GB, Taylor PL and McNeilly AS (1987) Effect of small doses of follicular fluid on the tonic secretion of gonadotropins in the ewe journal of Endocrinology 114 73-79

Martin GB, Price CA, Thiéry JC and Webb R (1988) Interactions between inhibin, oestradiol and progesterone in the control of gonadotrophin secretion in the ewe Journal of Reproduction and Fertility 82 319-328

Motta M and Martini L (1982) Effect of opioid peptides on gonadotropin secretion Acta Endocrinologica $99321-325$

Naylor AM, Porter DWF and Lincoln DW (1990) Central administration of corticotropin-releasing factor in the sheep: effects on secretion of gonadotrophins, prolactin and cortisol Journal of Endocrinology 124 117-125

Nikolarakis KE, Almeida OFX and Hertz A (1986) Stimulation of hypothalamic $\beta$-endorphin and dynorphin release by corticotropin-releasing factor (in vitro) Brain Research 399 152-155

Nikolarakis KE, Almeida OFX and Hertz A (1988) Hypothalamic opioid receptors mediate the inhibitory actions of corticotropin-releasing hormone on luteinizing hormone release: further evidence from a morphine tolerant animal model Brain Research 450 360-373

Norman RL (1994) Corticotropin-releasing hormone effects on luteinizing hormone and cortisol secretion in intact female rhesus macaques Biology of Reproduction 50 949-955

Oldfield EH, Schulte HM, Chrousos GP, Rock JP, Kornblith PL, O'Neill DL, Poplack DG, Gold PW, Cutler GB and Lariaux L (1985) Active clearance of corticotropin-releasing factor from the cerebrospinal fluid Neuroendocrinology 40 84-87

Olster DH and Ferin M (1987) Corticotropin-releasing hormone inhibits gonadotropin secretion in the ovariectomized rhesus monkey Journal of Clinical Endocrinology and Metabolism 65 262-267 
Papinot P, Caraty A, Locatelli A, Grino A and Oliver C (1989) CRF increase induced by insulin hypoglycaemia is associated with a decrease in LH-RH secretion into hypophyseal portal blood of castrated rams treated with testosterone Symposium on Neuroendocrine Regulation of Reproduction Serono Symposia, Napa (Abstract 31)

Parrott RF, Robinson JE and Thornton SN (1988) No change in LH pulse frequency or plasma oxytocin in castrated rams treated with corticotrophinreleasing hormone (CRH) Journal of Endocrinology Supplement 119 (Abstract 130)

Pelletier J, Kann J, Dolais J and Rosselin G (1968) Dosage radioimmunologique de l'hormone lutéinisante plasmatique chez le mouton. Mise au point de la technique de dosage Compte Rendus-Academie des Sciences (D) Paris 266 2291-2294

Petraglia F, Sutton S, Vale W and Plotsky PM (1987) Corticotropin releasing factor decreases plasma luteinizing hormone levels in female rats by inhibiting gonadotropin-releasing hormone release into hypophyseal portal circulation Endocrinology 120 1083-1088

Piva F, Limonta P, Maggi R and Martini L (1986) Stimulatory and inhibitory effects of the opioids on gonadotropin secretion Neuroendocrinology 42 504-512

Porter DWF, Lincoln DW and Naylor A (1990) Plasma cortisol is increased during the inhibition of $\mathrm{LH}$ secretion by central LHRH in the ewe Neuroendocrinology 51 705-712

Przekop F, Polkowska J and Mateusiak K (1984) The effect of prolonged stress on the hypothalamic luteinizing hormone-releasing hormone (LHRH) in the anoestrous ewe Experimental Clinical Endocrinology 91 334-340

Raisman G and Field PM (1973) Sexual dimorphism in the neuropil of the preoptic area of the rat and its dependence on neonatal androgen Brain Research 54 1-29
Rasmussen DD and Malven PV (1983) Effects of confinement stress on episodic secretion of $\mathrm{LH}$ in ovariectomized sheep Neuroendocrinology 36 392-396

Rivest S, Plotsky P and Rivier C (1993) CRF alters the infundibular LHRH secretory system from the medial preoptic area of male rats: possible involvement of opioids receptors Neuroendocrinology 57 236-246

Rivier CL and Plotsky PM (1986) Mediation by corticotropin releasing factor (CRF) of adenohypophyseal hormone secretion Physiological Review 48 $475-494$

Rivier C and Vale W (1984) Influence of corticotropin-releasing factor on reproductive functions in the rat Endocrinology $114914-921$

Rivier C, Rivier J and Vale W (1986) Stress-induced inhibition of reproductive functions: role of endogenous corticotropin-releasing factor Science 231 607-609

Saumande J, Tamboura D and Chupin D (1985) Changes in milk and plasma concentration of progesterone in cows after treatment to induce superovulation and their relationship with the number of ovulations and embryos collected Theriogenology 23 719-731

Siggins GR, Gruol D, Alderhof J and Pittman Q (1985) Electrophysiological action of corticotropin-releasing factor in the central nervous system Federation Proceedings 44 237-242

Skinner DC, Malpaux B, Delaleu B and Caraty A (1995) Luteinizing hormone (LH)-releasing hormone in third ventricular cerebrospinal fluid of the ewe: correlation with LH pulses and the LH surge Endocrinology 136 3230-3237

Van Vugt DA, Piercy J, Farley AE, Reid RL and Rivest S (1997) Luteinizing hormone secretion and corticotrophin-releasing factor gene expression in the paraventricular nucleus of Rhesus monkeys following cortisol synthesis inhibition Endocrinology 138 2249-2258 